${ }^{2}$ Krertman, N. (1962) Psychiatric orientation: A study of attitudes among psychiatrists. Journal of Mental Science, 108, 317-28.

${ }^{3}$ Toone, B. K., Murray, R., Clare, A., Creed, F. \& Smith, A (1979) Psychiatrists' models of mental illness and their personal backgrounds. Psychological Medicine, 9, 165-78.

'Pines, M. (1979) Chapter in Therapeutic Communities (eds. R. D. Hinshelwood and F. Manning). London: Routledge \& Kegan Paul.

'Lieberman, S. \& CoBb, J. (1983) Psychotherapy supervision: The attitudes of general psychiatrists. Bulletin of the Royal College of Psychiatrists, 7, 102-3.

'Wells, P. G., MorRis, A., Jones, R. M. \& Allen, D. J. (1978)
An adolescent unit assessed: A consumer study. British Journal of Psychiatry, 132, 300-8.

'Jones, R. M., Allen, D. J., Wells, P. G. \& MorRis, A. (1978) An adolescent unit assessed: Attitudes to a treatment experience for adolescents and their families. Journal of Adolescence, 2, 371-83.

'RAPOPORT, R. M. (1960) Community as Doctor. London: Tavistock.

${ }^{9}$ Wells, P. G. (1981) Adolescents in large groups: Confirming a model. Social Work with Groups, 4, 63-8.

${ }^{10}$ DHSS (1983) Medical and dental staffing prospects in the NHS in England and Wales, 1982. Health Trends, 15, 35-9.

\title{
Training in Psychiatry for Developing Countries (with special reference to Africa)
}

\author{
JoHN L. Cox, Senior Lecturer, Royal Edinburgh Hospital, Edinburgh
}

It was bold, as well as shrewd, to have held the 4th Conference of the African Psychiatry Association in London (Institute of Psychiatry) rather than Lagos or Lusaka. Yet Dr A. C. Raman (Consultant, St Augustine's Hospital and Secretary General of the Association) should be well satisfied with the rewards for his hard work. There were about 100 participants (the majority from Africa) who debated with vigour and courtesy the diverse facets of the conference theme. To have discussed these controversial training matters at the institution which, together with the department of psychiatry in Edinburgh, had influenced considerably the development of psychiatry in Nigeria, as well as in other Anglophone African countries, could have misfired. However, for most participants the conference presented a rare opportunity for legitimate nostalgia, as well as the chance to contribute to discussion on the present training of psychiatrists in Africa.

The conference proceeded with its work under the eagle eye of its President, Professor Binitie from Nigeria, with Dr Raman as both the organizing secretary and translator of the English and French language. The participants were indeed an unusual amalgam of African psychiatrists (predominantly from Nigeria), Europeans currently working in Africa, and at least one psychiatrist (Dr Ben-Tovim) who had recently returned to the UK from Botswana.

Several African trainees working in London were present as well as two African Consultants from the Kingdom of Fife in Scotland and from the London commuter zone of Woodford Green. They added considerably to the poignancy of the conference debate about training and by their presence illustrated its hidden agenda.

Some of the other participants were the pioneers of African psychiatry, including Professors Tolani Asuni, Allen German and Alexander Borofika. Tribute was also given at the opening session by Dr Momar Gueye to the memory of Professor Henri Collomb from Senegal, and by Professor German to Dr Joseph Muhangi from Uganda.

Once the initial formalities were over, and the Canterbury and Thanet Health Authority put on the map, participants then tackled their main agenda, the underlying theme being the appropriateness of psychiatric training in Britain for work in Africa, methods of evaluating such programmes and the differences between training courses on offer from UK teaching centres. The relevance of psychoanalysis for training African psychiatrists was also discussed and, though questioned by some, was vigorously defended by others; the delegates from French-speaking African countries being vociferous in advocating the value of a psychoanalytic approach to patient management.

However, the most important issue discussed, and predictably the most controversial, was the proposal by the Institute of Psychiatry to establish a two-year diploma in Psychological Medicine to meet the specific training needs of overseas psychiatrists. Professor G. Russell (Institute of Psychiatry) introduced this proposal cautiously and explained that much thought had already been given to this new course which was being put forward because of recent criticism of the teaching of overseas psychiatrists, increased difficulty of the MRCPsych, termination of the conjoint DPM and the need to develop training that was more suitable for the work of an overseas psychiatrist.

The audience listened to this suggestion, attempted to understand its origins, but disagreed with its main tenets. The objections were couched politely and hinged around the belief that African trainees, who were the future leaders of psychiatry in their countries, needed a thorough and vigorous training. Professor Ebie from Nigeria pointed out that the levels of clinical responsibility for an African 
psychiatrist were often higher than those expected initially of a British consultant and there was also a wide range of teaching tasks to be carried out in addition to the need to advise national governments.

The debate was absorbing and yet quite predictable. The author's memories returned to the examination of the second African candidate for the Makerere M Med in Psychiatry who failed the neurological case because of difficulty in eliciting a cranial nerve abnormality, and who also did poorly in a neurophysiology viva. How would a present-day UK trainee manage with a similar academic task, he wondered?

The Africans therefore still desired an internationally accepted and full postgraduate training. They were not enthusiastic about the proposed new DPM, although they did recognize that there were difficulties in fully implementing their own programmes.

The results of a survey carried out by Dr Famuyiwa and the author had shown that there was still a desire for African psychiatrists to have part of their training in Europe, and more surprisingly perhaps, that most British teachers continued to recognize the need to provide this training.

The other papers presented were on more familiar themes such as the need for community psychiatric nurses, generic social workers and for making mental health expertise available to primary care workers. Professor R. Cawley (Maudsley Hospital) outlined the proposed changes of the MRCPsych examination, and reminded the conference of the high failure rate for overseas trainees. He did recognize, however, that most overseas trainees who had difficulty in passing the exam were not usually from Africa.

The five-day conference concluded with the recommendation that expressed concern regarding the new DPM examination, as well as underlining the hope that collaboration would continue between postgraduate institutes in Africa and Britain.

It was apparent that neither the increase of fees now charged for overseas trainees nor the British colonial legacy had diminished the stimulus that results when professional interchange occurs between African and British psychiatrists. It might be appropriate, therefore, for the Royal College of Psychiatrists to hold a quarterly meeting in Nairobi, rather than Nottingham, and then to consider 'Training in psychiatry for European countries (with particular reference to Britain)'.

\section{Reviews}

Health Care and Its Costs: The Development of the National Health Service in England. Department of Health and Social Security. London: HMSO. 1983. Pp 51.£5.95.

Health Care and Its Costs is a government publication which at first sight provides an impressive picture of an expanding National Health Service in Britain. As it points out in the preface, more than 500,000 extra cases were treated either as in-patients or day cases in hospital in 1981 compared with 1978 . Within the body of the Report, there are figures for the corresponding increases in manpower. Between 1971 and 1981, the number of doctors and dentists increased by over 10,000; the number of nurses by over 70,000; the number of professional and technical staff by 26,000; and the number of administrative and clerical staff by 35,000 - to reach a total of 109,000. Against these figures, the publicity given to the recent small cuts in manpower budgets fall into a new perspective, which Norman Fowler has tried to bring out in the heated public debate of the past few months.

Turning to costs, in relation to psychiatry, the Report uses a rather dubious device. It shows that the hospital costs for mental illness have risen faster than any other sector-an increase of more than 60 per cent day between 1971-72 and 1981-82, compared to 10 per cent for acute hospitals, both in real terms. However, in showing the mental hospital costs as $£ 28$ per day, it makes it difficult to compare them with the cost of acute treatment at $\mathbf{6 4 9}$ per case. One has to divide this by the average length of stay of 8.6 days to discover that the acute hospitals receive almost three times as much per patient day as the mental hospitals. The excuse that mental hospital patients stay longer than acute hospital patients does not altogether justify this obscurantist method of presenting the comparative figures. Psychiatry may properly be a cheaper specialty than general medicine or surgery, but there is no need to try to hide their very striking difference by showing a disproportionate rise in mental hospital costs.

However, more fundamentally, what the Report shows is the relative fall in apparent work load for all categories of NHS staff. Numbers of both professional and unqualified employees have generally risen faster than the numbers of patients treated in the last decade. Admittedly, this is a point which the government has tactfully tried to bring out on several occasions, but the economic challenge implied in this situation has never been fully explored. Health care is becoming an increasingly labour intensive activity, and hence its costs must inevitably rise disproportionately in an increasingly affluent society, in which wage rates are rising faster than costs as a whole.

The government needs to face up to this and to enter into an honest debate with the electorate. If health care 